\title{
Near-highway aerosol and gas-phase measurements in a high-diesel environment
}

\author{
H. L. DeWitt ${ }^{1}$, S. Hellebust ${ }^{1}$, B. Temime-Roussel ${ }^{1}$, S. Ravier ${ }^{1}$, L. Polo ${ }^{2,3}$, V. Jacob ${ }^{2}$, C. Buisson ${ }^{3}$, A. Charron ${ }^{3}$, \\ M. André ${ }^{3}$, A. Pasquier ${ }^{3}$, J. L. Besombes ${ }^{4}$, J. L. Jaffrezo ${ }^{2}$, H. Wortham ${ }^{1}$, and N. Marchand ${ }^{1}$ \\ ${ }^{1}$ Aix Marseille Université, CNRS, LCE FRE 3416, 13331 Marseille, France \\ ${ }^{2}$ Université Grenoble Alpes, CNRS, LGGE, 38000 Grenoble, France \\ ${ }^{3}$ IFSTTAR, Case 24, 69675 Bron CEDEX, France \\ ${ }^{4}$ Université de Savoie, LCME, 73376 Le Bourget du Lac, France
}

Correspondence to: H. L. DeWitt (helen-langley.dewitt@univ-amu.fr) and N. Marchand (nicolas.marchand@univ-amu.fr)

Received: 26 September 2014 - Published in Atmos. Chem. Phys. Discuss.: 30 October 2014

Revised: 16 March 2015 - Accepted: 8 April 2015 - Published: 29 April 2015

\begin{abstract}
Diesel-powered passenger cars currently outnumber gasoline-powered cars in many countries, particularly in Europe. In France, diesel cars represented $61 \%$ of light duty vehicles in 2011 and this percentage is still increasing (French Environment and Energy Management Agency, ADEME).

As part of the September 2011 joint PM-DRIVE (Particulate Matter - DiRect and Indirect on-road Vehicular Emissions) and MOCOPO (Measuring and mOdeling traffic COngestion and POllution) field campaign, the concentration and high-resolution chemical composition of aerosols and volatile organic carbon species were measured adjacent to a major urban highway south of Grenoble, France. Alongside these atmospheric measurements, detailed traffic data were collected from nearby traffic cameras and loop detectors, which allowed the vehicle type, traffic concentration, and traffic speed to be quantified. Six aerosol age and source profiles were resolved using the positive matrix factorization model on real-time high-resolution aerosol mass spectra. These six aerosol source/age categories included a hydrocarbon-like organic aerosol (HOA) commonly associated with primary vehicular emissions, a nitrogen-containing aerosol with a diurnal pattern similar to that of HOA, oxidized organic aerosol (OOA), and biomass burning aerosol. While quantitatively separating the influence of diesel from that of gasoline proved impossible, a low HOA : black carbon ratio, similar to that measured in other high-diesel environments, and high levels of $\mathrm{NO}_{x}$, also indicative of diesel emissions, were observed. Although the measurement site
\end{abstract}

was located next to a large source of primary emissions, which are typically found to have low oxygen incorporation, OOA was found to comprise the majority of the measured organic aerosol, and isotopic analysis showed that the measured OOA contained mainly modern carbon, not fossil-derived carbon. Thus, even in this heavily vehicularemission-impacted environment, photochemical processes, biogenic emissions, and aerosol oxidation dominated the overall organic aerosol mass measured during most of the campaign.

\section{Introduction}

Aerosols are known to have adverse effects on human health and on the global climate. The World Health Organization (WHO) recently added anthropogenic aerosol and air pollution to their list of known carcinogens (WHO, 2013), and high mass concentrations of particles less than 2.5 micrometers in diameter $\left(\mathrm{PM}_{2.5}\right)$, such as those emitted by vehicular combustion processes, are particularly harmful (Lighty et al., 2000). Vehicular traffic is a large source of submicrometer anthropogenic aerosol and proximity to large sources of vehicular emissions has been shown to increase lung and heart disease, especially in children (Brugge et al., 2007). A recent WHO report examined the toxicological effects of black carbon (BC) aerosol, a known emission of diesel vehicles. Although no difference in toxicology between $\mathrm{PM}_{2.5}$ and $\mathrm{BC}$ aerosol inhalation was found, $\mathrm{BC}$ was cited as a marker for 
more general vehicular emissions which have been shown to have negative health effects; diesel exhaust was added as a known carcinogen the year before general air pollution and $\mathrm{PM}_{2.5}$ (Janssen, 2012). Aside from the potential detrimental health effects, BC also has significant implications for climate change. Unlike the majority of aerosol (e.g., most organic aerosol, ammonium sulfate, ammonium nitrate), BC aerosol is associated with global warming due to its high absorption of solar radiation (Bond et al., 2013). Diesel vehicles have been singled out as important sources of $\mathrm{BC}$ to regulate as, unlike most other BC sources, diesel vehicles tend not to co-elute high concentrations of other, less absorbing (thus more cooling) aerosol and therefore have a higher net heating effect than mixed-emission black carbon sources (Bond et al., 2013).

In France, the lower cost of diesel fuel (due to a lower taxation rate of diesel fuel versus gasoline fuel) and the generally higher fuel efficiency of diesel engines have increased the popularity of diesel passenger cars. In 2011, $82 \%$ of the fuel consumed in France was diesel (World Bank, 2011). For comparison, this percentage in 2011 was $28 \%$ in the US, $57 \%$ in China, $70 \%$ in the European Union, $49 \%$ in Latin America and the Middle East, and $83 \%$ in low-income countries.

The emission characteristics and emission limits of these two types of engines (diesel and gasoline) are quite different: diesel vehicles have higher emission factors for primary organic aerosol (POA) and BC, while gasoline-powered vehicles have higher emission factors for carbon monoxide $(\mathrm{CO})$, carbon dioxide $\left(\mathrm{CO}_{2}\right)$, and volatile organic carbon (VOCs) (e.g., trimethylbenzene, benzene) (Platt et al., 2013). Black carbon, in particular, is closely associated with diesel: in Europe, North America, and Latin America, an estimated $70 \%$ of $\mathrm{BC}$ emissions are from diesel-powered vehicles (Bond et al., 2013). In Marseille, France, a traffic tunnel experiment measured an organic carbon/elemental carbon ratio (OC / EC) in $\mathrm{PM}_{2.5}$ of $0.3-0.4$, which indicates that significant amounts of black carbon is emitted from local traffic in Marseille (El Haddad et al., 2009). Recent measures have been taken in Europe to reduce the particulate emission from diesel vehicles: from Euro 4 to Euro 5, a diesel particle filter was introduced in diesel vehicles and the regulated emission limit for $\mathrm{PM}_{2.5}$ was halved for diesel cars and trucks.

Aerosol and VOC emissions from both vehicle types, as well as biogenic emissions, industrial emissions, and emissions from other sources, will react together in the atmosphere and potentially form secondary organic aerosol (SOA). Thus, primary aerosol emissions may not be the most important emission factor to take into account for global reduction in anthropogenic aerosol. After emission, VOCs can react in the atmosphere and form SOA. From these reactions, gasoline VOC emissions could ultimately lead to the formation of higher concentrations of organic aerosol than organic aerosol released directly from diesel vehicles, as reported in a recent study comparing the SOA formation from a Euro 3 diesel light-duty vehicle (LDV) and a Euro 5 gasoline LDV (Platt et al., 2013).

A recent study by Bahreini et al. (2012) measured similar levels of SOA in the heavily traffic-influenced Los Angeles Basin during both weekend and weekday afternoons. While diesel-powered vehicle numbers on the road decrease significantly on the weekends in the LA area, the measured SOA does not, which leads to the conclusion that gasoline emissions are more responsible for SOA than diesel emissions (Bahreini et al., 2012). Nordin et al. (2013) performed smogchamber studies on SOA formation from gasoline-vehicle VOC emissions during simulated cold start and idling driving conditions and confirmed the high potential of SOA formation from gasoline car exhaust. Another recent paper calculates the reactivity potential of diesel and gasoline fuel and comes to the opposite conclusion: due to the reactivity potential of diesel fuel, diesel-powered vehicles should contribute greater amounts of SOA than gasoline-powered vehicles to the atmosphere (Gentner et al., 2012). Thus, controversy still exists regarding the eventual aerosol emission factors of diesel and gasoline engines when considering both primary emissions and potential SOA formation.

Finally, gas-phase $\mathrm{NO}$ and $\mathrm{NO}_{2}\left(\mathrm{NO}_{x}\right)$ ambient concentrations are also mostly associated with diesel fuel use (Vestreng et al., 2009). Throughout Europe, while $\mathrm{NO}_{x}$ emission standards for diesel vehicles have increased in stringency in recent years, ambient $\mathrm{NO}_{2}$ levels have not shown a corresponding decrease (Vestreng et al., 2009). The reduction of atmospheric $\mathrm{NO}_{x}$ is important for health-related reasons, as an increase in $\mathrm{NO}_{x}$ leads to an increase in tropospheric ozone, which is a known lung irritant. $\mathrm{NO}_{x}$ levels have also been shown to affect the formation rate, formation pathways, and chemical composition of secondary organic aerosol from the reaction of primary species in numerous chamber studies (e.g., Carlton et al., 2009; Kroll et al., 2005; Ng et al., 2007, 2008; Presto et al., 2010).

European vehicular emissions, near-highway pollution levels, and the chemical composition of highway pollution may be quite different than those measured in North America due to many factors, including (1) different emission standards and fuel regulations in the two regions, (2) different after-treatment devices to reduce the emission of certain pollutants, and (3) a much larger percentage of diesel-powered passenger cars on the road. A comparison between European and North American near-highway measurements could lead to further understanding of the effects of diesel versus gasoline on near-highway atmospheric chemistry.

To fully categorize the aerosol, VOC, and $\mathrm{NO}_{x}$ emissions of traffic in France, the joint PM-DRIVE (Particulate Matter-DiRect and Indirect on-road Vehicular Emissions) and MOCOPO (Measuring and mOdeling traffic COngestion and POllution) field mission took place in the Grenoble basin, France, during the fall of 2011 at a near-highway location south of the city center. During the field measurements discussed in this paper, traffic cameras allowed vehicle 
type determination through license plate automatic identification. Traffic densities, speed, and total flow were quantified through loop detectors, while measurements of the chemical composition, concentration, and size of aerosol were collected using both real-time and offline analysis, and parallel data on the gas-phase chemical composition of the roadwayadjacent environment were also collected. A source apportionment model was applied to real-time aerosol chemical composition data. Particular attention was paid to the chemical composition of particles and VOCs emitted during morning and evening rush hours in an attempt to elucidate the primary vehicular influence on near-highway air pollution.

\section{Experimental methods}

\subsection{Description of the measurement site}

The sampling site was located at $45.150641^{\circ} \mathrm{N}, 5.726028^{\circ} \mathrm{E}$ (Fig. 1), just south of Grenoble, France, adjacent to a major highway (south of E712, with A480 $2 \mathrm{~km}$ to the east). During the week, the total traffic on the highway was about 95000 vehicles day ${ }^{-1}$ (65000 during the weekend). Grenoble, a large city with over half a million people, is located in the southeast of France at the foothills of the Alps. The surrounding mountain ranges both buffer the Grenoble area from the effects of transported aerosol and trap pollution within the valley, particularly during the winter months and periods of temperature inversions. The isolating effect of the mountains thus simplifies the potential sources for aerosol, making it an interesting location for the study of specific aerosol emission sources.

\subsection{Traffic cameras and loop detectors}

Traffic cameras mounted to a roadway sign were used to capture the license plate numbers of vehicles driven on the highway close to the field measurement site. These numbers were later used to classify vehicular traffic into different categories: vehicle type (LDV, heavy-duty vehicles, buses) and age, vehicle size and engine capacity, fuel type (diesel or gasoline), and Euro number (i.e., the pollutant emission regulation that the vehicle complies with). The speed of the passing vehicles was also monitored with the classical traffic detector (double electromagnetic loops able to identify the passing of all vehicles and their speeds), which allowed the identification of periods of stop-and-go, dense, or free-flow traffic.

\subsection{MASSALYA platform}

The MASSALYA platform is a mobile laboratory equipped for air quality measurements with a hub located at the AixMarseille Université. For the field campaign, $\mathrm{PM}_{2.5}$ and $\mathrm{PM}_{1}$ sampling heads situated above the roof of the stationary truck were connected to a variety of online instrumentation located within the truck body. Complementary offline analysis was performed on filter samples collected by HiVol samplers located adjacent to the MASSALYA platform. All sampling occurred approximately $15 \mathrm{~m}$ from one of the traffic lines, as shown in Fig. 1. Further details can be found in PoloRehn (2013).

A high-resolution time-of-flight aerosol mass spectrometer (HR-ToF-AMS, Aerodyne) was used to analyze the chemical composition, size, and concentration of non-refractory submicrometer particles in the ambient atmosphere (DeCarlo et al., 2006). Instrument specifications have been discussed in detail elsewhere (DeCarlo et al., 2006). Briefly, both highresolution and size-speciated chemical information for ambient aerosol were obtained from this instrument. Aerosols were vaporized at $600{ }^{\circ} \mathrm{C}$, ionized using electron ionization at an energy of $70 \mathrm{eV}$, and the chemical composition of bulk aerosol was measured using a ToF mass spectrometer (TOFWERK). Aerosol spectra were continuously collected and a $2.5 \mathrm{~min}$ average spectrum was obtained. Aerosol vacuum aerodynamic diameter was calculated by setting a particle start time using a chopper wheel and measuring the particle flight time along the particle ToF sizing region (DeCarlo et al., 2006). Typical resolution during the campaign was around $2800 \mathrm{~m} / \Delta m$ (where $\mathrm{m}=$ nominal $\mathrm{m} / \mathrm{z}$ and $\Delta m=$ full-width at half max of the mass peak).

In addition to the HR-ToF-AMS, a size-mobility particle scanner (SMPS, TSI) was used to measure the size distribution and concentration of ambient aerosol and a multiangle absorption photometer (MAAP 5012, ThermoFischer) was used to measure the concentration of black carbon.

High-resolution mass spectra of VOCs were obtained using an Ionicon proton-transfer-reaction time-of-flight mass spectrometer 8000 (PTR-ToF-MS, hereafter referred to as PTR-MS) (Graus et al., 2010). The PTR-MS analyzes trace (parts per trillion by volume) VOCs with high mass resolution, which allows the separation of different species with the same nominal mass and the identification of each peak's elemental formula. The PTR-MS was run with a $25 \mathrm{~s}$ time resolution and a flow of $100 \mathrm{~cm}^{3} \mathrm{~min}^{-1}$. Drift tube parameters of the PTR-MS were as follows: voltage was $560 \mathrm{~V}$, drift tube pressure was $2.11 \mathrm{mbar}$, and drift tube temperature was $333 \mathrm{~K}$, resulting in an $E / N$ (electric field / number concentration of neutral particles) of $133 \mathrm{Td}$.

The SMPS, PTR-MS, and HR-ToF-AMS were connected to the same sample inlet with a $\mathrm{PM}_{2.5}$ sampling head and a sample flow of $1 \mathrm{~m}^{3} \mathrm{~h}^{-1}$. Particles were dried $(\mathrm{RH}<30 \%)$ using a Nafion dryer prior to measurement with the HR-ToFAMS and SMPS. The MAAP was connected to a separate $\mathrm{PM}_{1}$ sampling head. $\mathrm{PM}_{1}$ filter HiVol $\left(30 \mathrm{~m}^{3} \mathrm{~h}^{-1}\right)$ samples were collected on quartz filters (Tissuquartz) on a daily basis and analyzed for radiocarbon isotope data. Radiocarbon measurements were conducted at Saclay (CNRS-CEA-IRDIRSN, France) using ARTEMIS accelerator mass spectrometry on the total carbon (TC) fraction after a combustion of 

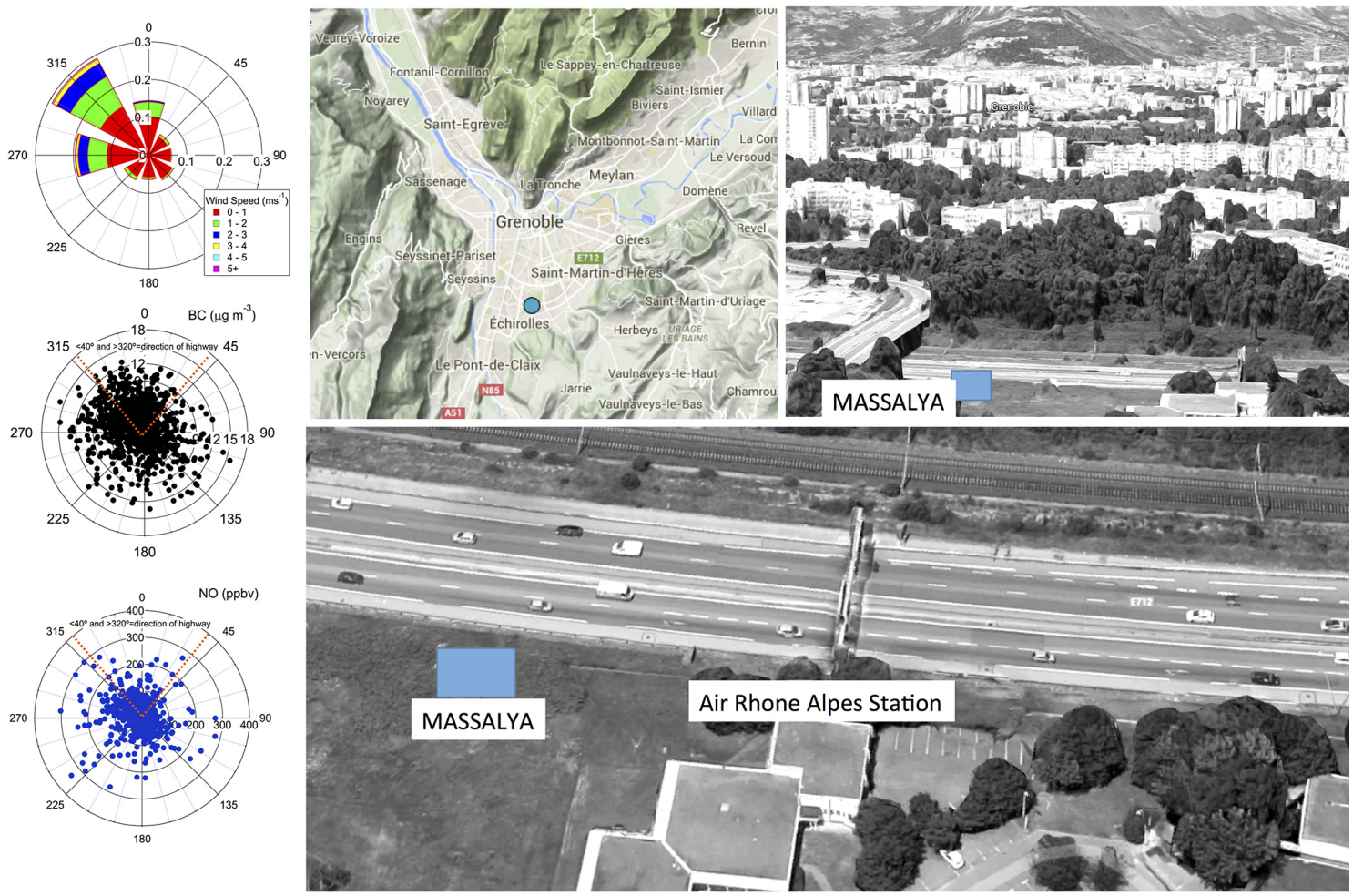

Figure 1. The measurement site location is marked by a red square on the map, and the adjacent highway has been colored in red. A detailed view of the measurement site and the two measurement stations is shown in the lower right-hand corner; in the upper right-hand corner is the wind rose and polar plots for black carbon and NO, with the red lines denoting the direction of the highway. Grenoble is to the north.

the samples at $850^{\circ} \mathrm{C}$. The method is fully described in $\mathrm{El}$ Haddad et al. (2011).

A Young meteorological station was also installed to capture wind speed, wind direction, relative humidity, and temperature data at the measurement location.

\subsection{Air Rhône-Alpes station}

The Air Rhône-Alpes station collected $\mathrm{PM}_{2.5}$ HiVol $\left(30 \mathrm{~m}^{3} \mathrm{~h}^{-1}\right)$ samples on quartz fiber filters (Tissuquartz) $20 \mathrm{~m}$ east of the MASSALYA platform, still adjacent to the highway, with a time resolution of $4 \mathrm{~h} . \mathrm{PM}_{2.5}$ samples were analyzed for EC / OC, inorganic ions, and targeted organic tracers (Polo-Rehn, 2013).

Organic compounds in these PM samples were also quantified by gas chromatography coupled with mass spectrometry, following the method detailed in El Haddad et al. (2009) and Favez et al. (2010). EC and OC measurements were performed using the thermal-optical transmittance (TOT) method on a Sunset Lab analyzer (Birch and Cary, 1996; Jaffrezo et al., 2005) following the EUSAAR2 temperature program (Cavalli et al., 2010). Ionic species were analyzed with ionic chromatography following the method described in Jaffrezo et al. (1998).
All filters used in this study were preheated at $500^{\circ} \mathrm{C}$ during $3 \mathrm{~h}$. Samples were stored at $-18^{\circ} \mathrm{C}$ in aluminum foil and sealed in polyethylene bags until analysis.

In addition, $\mathrm{NO}_{x}\left(\mathrm{NO}\right.$ and $\left.\mathrm{NO}_{2}\right), \mathrm{PM}_{10}$, and $\mathrm{PM}_{2.5}$ mass concentrations were measured and a tapered element oscillating microbalance equipped with a filter dynamic measurement system (TEOM-FDMS, Thermo Scientific) was used for real-time measurements of $\mathrm{PM}_{10}$ and $\mathrm{PM}_{2.5}$.

\section{Results and discussion}

\subsection{Traffic conditions at the measurement site}

A detailed view of the measured traffic is presented in the Supplement (Fig. S1). Briefly, the overall makeup of the traffic remained fairly steady throughout the campaign. The bulk of the vehicles directly affecting the measurement site were Euro 4 (released in 2005) or older; thus, the most recent emission regulations had only a small effect on the air quality around the field site. The ratio of diesel to gasoline cars was found to be 2.6 , or $72 \%$ diesel, with a high correlation $\left(R^{2}=0.96\right)$ between diesel and gasoline vehicles. 


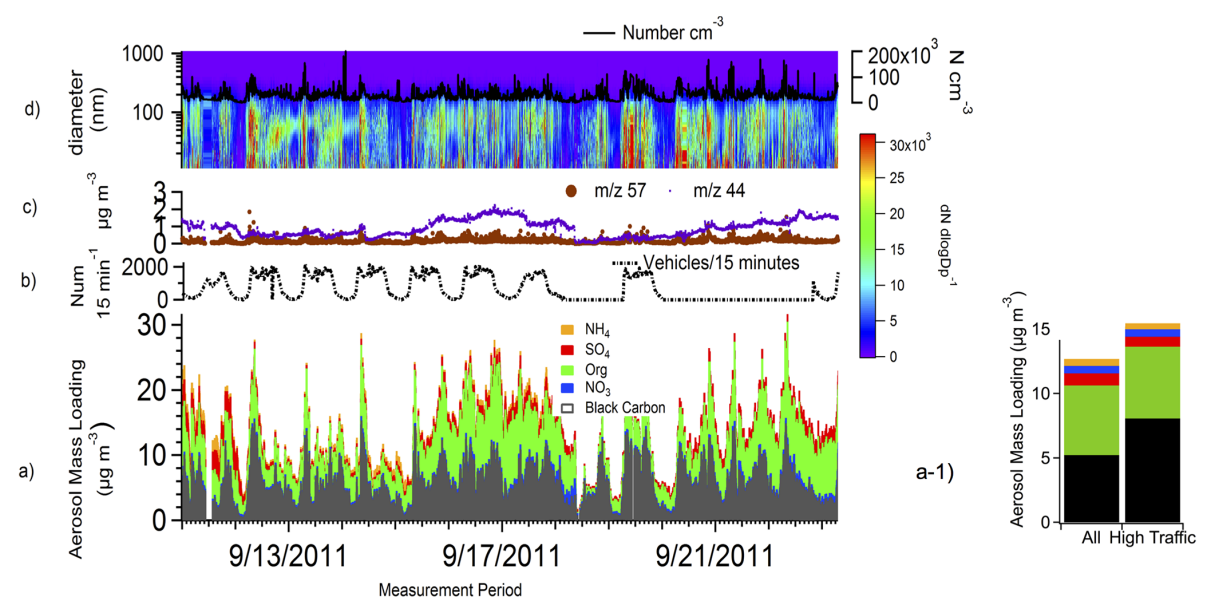

Figure 2. The non-refractory submicrometer aerosol concentration in $\mu \mathrm{g} \mathrm{m}^{-3}$ of $\mathrm{SO}_{4}, \mathrm{NH}_{4}, \mathrm{NO}_{3}$, and organic species is plotted along with black carbon for the campaign time series. (a) Traffic concentration $15 \mathrm{~min}$ (missing data due to malfunction in the traffic cameras on those days); (b) $\mathrm{COO}^{+}(\mathrm{m} / \mathrm{z} 44)(\mathbf{c})$ and $\mathrm{C}_{4} \mathrm{H}_{9}^{+}(\mathrm{m} / \mathrm{z}$ 57); and (d) the number-weighted geometric size distribution with the total number concentration of particles as a function of time (right axis). The inset (a-1) shows average concentrations of the species in (a) for high-traffic and all traffic periods. The color legend is the same for (a) and (a-1).

\subsection{General atmospheric conditions and aerosol and VOC concentrations and evolution}

Wind speeds were generally low throughout the campaign $\left(<1-2 \mathrm{~m} \mathrm{~s}^{-1}\right)$ with higher wind speeds peaking in the afternoons and tapering off in the evenings. The wind direction was primarily from the northwest, from the direction of the nearby highway. A diagram of the two measurement stations, the wind rose plot for the MASSALYA location, and polar plots showing the concentration of $\mathrm{NO}$ and $\mathrm{BC}$ as a function of wind direction are shown in Fig. 1. BC and NO were associated with all wind directions, though slightly higher from the highway direction, which suggested that the measurement site was influenced by both traffic emissions and also often by regional, traffic-influenced background air masses. In order to better describe the traffic influence, we defined high-traffic (HT) periods within the data set. These HT periods were selected as follows: (i) wind direction $>40$ or $<320$, (ii) NO in the 75th percentile, (iii) from 06:30 to 09:30 or 17:00 to 20:00 LT (rush hour periods). The fixed location of the measurement stations made determination of concentration drop-off as a function of distance from the roadway impossible with the data set, although that has been shown to be important in other studies (such as Karner et al., 2010). However, the measurements were all taken closer to the roadway $(\sim 15 \mathrm{~m})$ than the calculated distance where roadway emission drops off to background levels (115-570 m, Karner et al., 2010).

The campaign time series concentration of submicrometer non-refractory aerosol sulfate $\left(\mathrm{SO}_{4}\right)$, ammonium $\left(\mathrm{NH}_{4}\right)$, nitrate $\left(\mathrm{NO}_{3}\right)$, and organic species from the HR-ToF-AMS is shown in Fig. 2a. The limit of detection for each species was calculated using the method described by DeCarlo et al. (2006) and found to be $0.30,0.21,0.06$, and $0.33 \mu \mathrm{g} \mathrm{m} \mathrm{m}^{-3}$ for $\mathrm{SO}_{4}, \mathrm{NH}_{4}, \mathrm{NO}_{3}$, and organic aerosol, respectively, for our measurements with a time resolution of $2.5 \mathrm{~min}$. A collection efficiency (CE) of 0.75 was applied to HR-ToF-AMS aerosol concentration measurements taken during this campaign. The $\mathrm{CE}$ factor compensates for incomplete vaporization of non-refractory species due to particle bounce, the likelihood of which changes with particle phase and chemical speciation (Huffman et al., 2005; Matthew et al., 2008). This CE was calculated by comparing the HR-ToF-AMS $\mathrm{SO}_{4}$ concentrations to $4 \mathrm{~h}$ filter concentrations (Fig. S2). This comparison gave a value of $0.75 \pm 0.03$ for the slope between the two types of measurements.

$\mathrm{PM}_{2.5}$ averaged $17 \mu \mathrm{g} \mathrm{m}^{-3}$ for the campaign (Fig. S3) while $\mathrm{PM}_{10}$ averaged $22 \mu \mathrm{g} \mathrm{m}^{-3}$. These values increased slightly during HT periods (a 1.3 and $1.25 \times$ increase, respectively). Black carbon and organic aerosol species dominated the measured aerosol composition throughout the campaign, and comprised 39 and $40 \%$ of the total speciated submicrometer aerosol, respectively. $\mathrm{PM}_{2.5}$ had a somewhat higher mass variation than the AMS $+\mathrm{BC}$ measured mass (Fig. S3), likely due to the smaller measurement size cutoff for AMS $(1 \mu \mathrm{m})$ and the presence of road dust in the local environment, a large portion of which may be nonrefractory and thus unable to be measured by the AMS. Increases in $\mathrm{BC}$ and the aerosol marker $m / z 57\left(\mathrm{C}_{4} \mathrm{H}_{9}^{+}\right)$, a marker for primary organic carbon in the HR-ToF-AMS (Zhang et al., 2005), correlated in time to the observed morning and evening traffic peaks (Fig. 2b), with BC levels reaching $10-16 \mu \mathrm{g} \mathrm{m}^{-3}$ during the mornings (Fig. 2a) for $2.5 \mathrm{~min}$ averaged measurements. As expected, an increase of BC and $m / z 57(1.5 \times)$ was observed during HT periods. Note that $\mathrm{BC}$ concentrations during high filter loadings (BC accumula- 
tion rate $>0.14 \mu \mathrm{g} \mathrm{min}^{-1}$ ) have been removed to compensate for the underestimation of $\mathrm{BC}$ by the MAAP during periods of high concentrations (Hyvärinen et al., 2013). Along with increased concentrations of $m / z 57$ and $\mathrm{BC}$, elevated number concentrations of small particles (up to $1-2 \times 10^{5} \mathrm{~cm}^{-3}$ during peaks from daily base levels of $2-4 \times 10^{4} \mathrm{~cm}^{-3}$ ) were observed during periods of HT (Fig. 2d), for 5 min measurements. BC and $m / z 57$ had similar daily averages throughout the campaign; however, overall organic concentration rose significantly during the period from 12 to 14 September and 15 to 17 September, when particle growth events were observed (Fig. 2d). The geometric number mode diameter rose over the course of each day to a maximum diameter each afternoon, when photochemical processing was the most intense. A marker for oxidized, aged organic aerosol (Fig. 2c, $m / z 44, \mathrm{COO}^{+}$) also rose in concentration during this time period, further confirming that the larger aerosol and higher organic mass concentrations were due to aging and secondary organic aerosol formation processes. A period of heavy rain on 18 and 19 September removed much of the organic aerosol from the local atmosphere. Black carbon concentrations and small particle concentrations quickly returned to their previous levels. A new accumulation period was observed after rainfall (Fig. 2d), with the mode diameter of particles increasing as secondary aerosol was formed again. The slow rise of organic concentration during these periods, the lower $\mathrm{BC}$ : organic mass ratio, the enhancement of organic concentration outside of normal traffic periods, and the low level of NO during these accumulation periods all suggest that this increase in organic aerosol concentration was driven by regional influences, not by nearby vehicular emissions; a more southerly wind direction during this time confirmed the transport of non-highway air masses to the measurement site.

These findings are similar to those presented recently by Sun et al. (2012), who measured aerosol size and chemical composition adjacent to the Long Island Expressway in New York and observed that traffic-influenced aerosol emissions were primarily small particles which varied in concentration with changes in traffic throughout the day. During periods with less traffic influence, more-oxygenated organic aerosol (OOA) and inorganic ions with larger mode diameters and lower temporal variations were observed (Sun et al., 2012).

The time series concentrations of selected VOC peaks are shown in Fig. 3. Primary traffic-related VOC species, such as aromatics (benzene and trimethylbenzene), were found to have high temporal variations similar to those of trafficrelated aerosol species and $\mathrm{NO}_{x}$ (Fig. $4 \mathrm{c}$ and d). $\mathrm{NO}_{x}$ levels were often over $400 \mathrm{ppbv}$ during the morning rush hours, while the PTRMS peak corresponding (in part) to toluene and benzene peaked around 2 to $1 \mathrm{ppbv}$ (respectively). During a recent chamber study in Ispra, Italy, fresh diesel emissions PTR-MS VOC spectra were found to contain peaks with the same mass as $\mathrm{CH}_{4} \mathrm{NO}_{2}^{+}$and $\mathrm{C}_{2} \mathrm{H}_{5} \mathrm{O}^{+}$(Hellebust et al., 2013), which are not present in fresh gasoline emis-

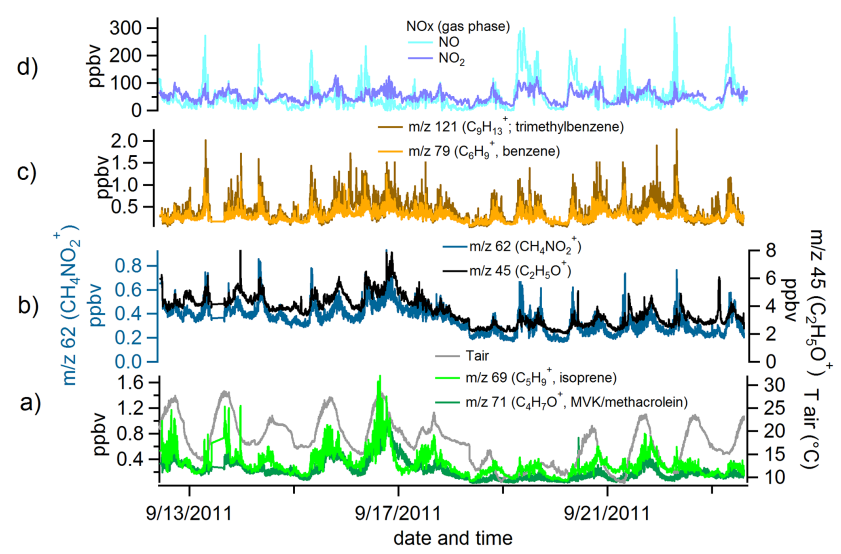

Figure 3. The concentration in ppbv of PTR-MS VOC speciesidentified isoprene and methyl vinyl ketone/methacrolein (left axis, a), VOC species associated with diesel exhaust $\left(\mathrm{CH}_{4} \mathrm{NO}_{2}^{+}\right.$, $\mathrm{C}_{2} \mathrm{H}_{5} \mathrm{O}^{+}$, b), VOC species associated with gasoline exhaust $\left(\mathrm{C}_{6} \mathrm{H}_{7}^{+}, \mathrm{C}_{9} \mathrm{H}_{13}{ }^{+}, \mathbf{c}\right)$. $\mathrm{NO}$ and $\mathrm{NO}_{2}$ (gas-phase) ppbv concentrations (d) and ambient temperature (right axis, a) during the measurement period are also shown.

sions. These same peaks were also observed during this work and found to vary with traffic during this measurement period but had a smoother variation than the observed aromatics (Fig. 3b). While this species is unique for fresh diesel emissions versus gasoline emissions, aging processes occur rapidly and other sources may contribute to this mass peak. Thus, these species, while increasing with traffic, cannot be assumed to be tracers for primary diesel emissions in particular; no high-concentration unique tracer peak for diesel VOC emissions was resolved from the fresh diesel emission spectra in these chamber experiments (Hellebust et al., 2013). A slight increase of the traffic-related VOCs $(1.2 \times$ for benzene and trimethylbenzene) was observed during HT periods compared to the campaign average. For $\mathrm{CH}_{4} \mathrm{NO}_{2}^{+}$this relative increase during HT periods is lower $(8 \%)$, which could confirm multiple sources of this compound.

In addition to traffic-related VOC emissions, mass peaks corresponding in exact mass to biogenic emissions, such as isoprene, were measured in ppbv levels. These peaks were found to rise in concentration with the ambient temperature (Fig. 3a), typical of isoprene peaks. The presence of isoprene and its oxidation product, methyl vinyl ketone, or its isomer methacrolein in similar concentrations as that of the major traffic-related VOC peaks (ppbv levels) suggested that biogenic emissions also significantly influenced the local atmosphere despite close proximity to anthropogenic emission sources (i.e., road traffic).

The high morning concentrations of traffic-related pollutants, compared to evening concentrations, were caused in part by a low early morning boundary layer that rose during the day and fell during the night. Boundary layer heights (BLH) were estimated using the Hybrid Single Particle La- 


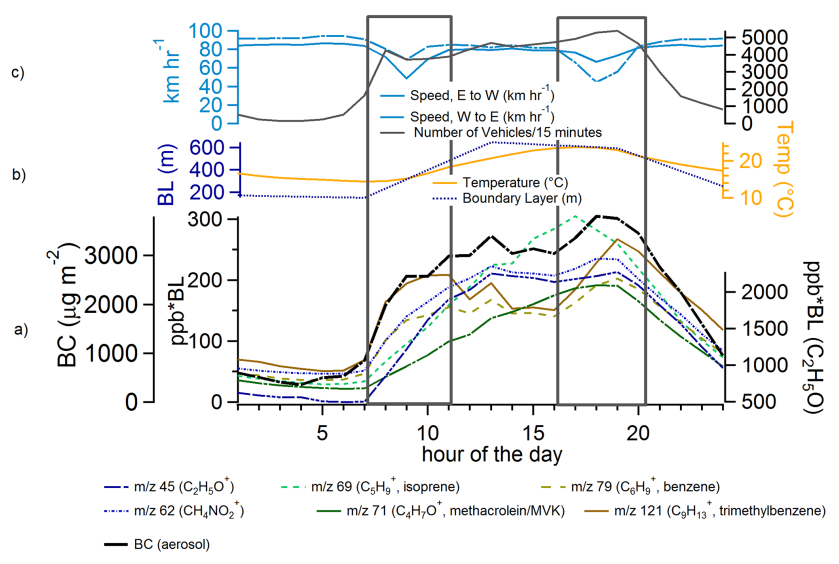

Figure 4. Diurnal profiles of boundary-layer scaled VOC peaks from PTR-MS measurements and BC peaks from MAAP measurements (a), temperature (right axis, b), boundary layer height (left axis, b), vehicular speed (left axis, c), and vehicle concentration (right axis, c).

grangian Integrated Trajectory (HYSPLIT) back-trajectory model. The HYSPLIT model either extracts the BLH from meteorological file input into the model or, if no BLH exists in the meteorological file, BLH is estimated using the vertical temperature profile. A selection of the BLH-scaled diurnal profiles of traffic and biogenic emission-related VOC concentrations are shown in Fig. 4a along with traffic (speed, vehicular flux) diurnal profiles and the calculated boundary layer heights and measured temperatures (Fig. 4b and c). This calculation was performed to more directly compare vehicle concentration and speed to vehicular emissions and temperature with biogenic emissions (by removing the dilution of emissions by the changing boundary layer height). Biogenic species, such as isoprene, peaked in concentration during the afternoon, when temperatures were the warmest. Aromatic species peaked in concentration, even after the rough boundary layer scaling was applied, during periods of low speeds. This is consistent with other findings that show cold starts and idling speeds cause an increase in aromatic VOC emissions from gasoline-powered vehicles (e.g., Broderick and Marnane, 2002).

\subsection{Positive matrix factorization (PMF) analysis}

The PMF model was applied to the HR-ToF-AMS aerosol data using the process described in detail by Ulbrich et al. (2009). Six aerosol factors were resolved by their source and relative aging using the PMF model: a hydrocarbon-like organic aerosol (HOA) factor, a regional oxidized organic aerosol (OOA-Reg) factor associated with sulfate aerosol, two oxidized organic aerosol factors with opposing diurnal patterns, one more oxidized than the other (less-oxidized organic aerosol, or LO-OA, with peak concentration during the mornings/nights, and more-oxidized organic aerosol, or

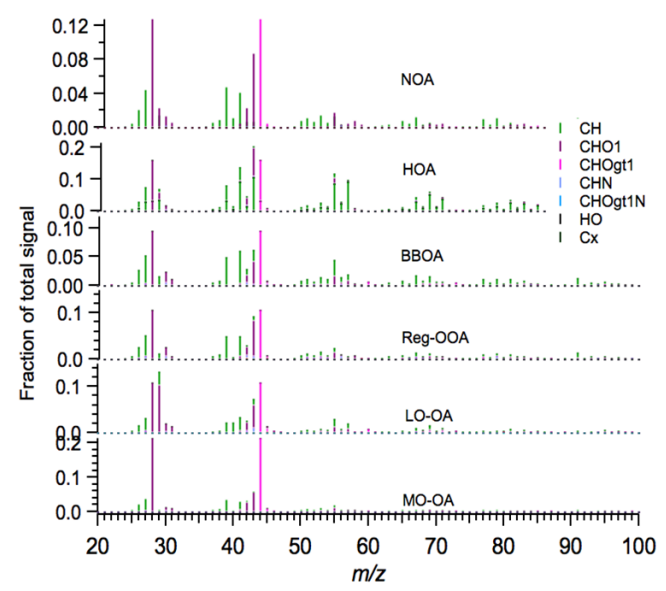

Figure 5. The mass spectra of the six resolved factors, moreoxidized organic aerosol (MO-OA), less-oxidized organic aerosol (LO-OA), regional oxidized organic aerosol (OOA-Reg), biomass burning organic aerosol (BBOA), hydrocarbon-like organic aerosol (HOA), and nitrogen-containing organic aerosol (NOA). Fraction of total signal is plotted against $\mathrm{m} / \mathrm{z}$ and the peaks are color-coded to show their high-resolution identifications.

MO-OA, with peak concentrations during the afternoons), a biomass-burning organic aerosol factor (BBOA), and a nitrogen-containing organic aerosol factor (NOA). The mass spectra for the six resolved factors is shown in Fig. 5, labeled with their identifications. Evaluation graphs for the six-factor PMF solution are shown in the Supplement (Figs. S5-S8). Polar plots of the factor concentrations and wind direction are shown in Fig. S9. A six-factor solution was the lowest number of factors where a BBOA factor was resolved; BBOA was suspected to be present in the air mass measured during the campaign due to periods of increased levoglucosan measured on filter samples. However, its concentrations were very low $\left(15 \mathrm{ng} \mathrm{m}^{-3}\right.$ on average; Polo-Rehn, 2013) compared to concentrations measured in Grenoble in winter (around $800 \mathrm{ng} \mathrm{m}^{-3}$; Herich et al., 2014). Solutions with more than six factors appeared to split the OOA factor further until differences between each OOA factor were difficult to justify. The calculated elemental ratios of $\mathrm{O}: \mathrm{C}, \mathrm{H}: \mathrm{C}$, and organic mass: organic carbon (OM:OC) (Aiken et al., 2008) are shown in Table 1.

The diurnal pattern and the relative concentrations of each resolved factor, averaged over the campaign period, are shown in Fig. 6, along with the standard deviation of their concentrations. Morning and evening peaks, correlating in time to rush hour traffic, were clearly observable for the HOA factor. Also clearly visible in Fig. 6a are the opposing diurnal trends of LO-OA (peaking at night and early morning) and MO-OA (peaking around 3 p.m. LT each afternoon). OOAReg had no discernable diurnal trend. An interesting finding in these data is that the HOA and NOA factor concentrations both peaked during morning and evening high-traffic peri- 
Table 1. PMF factors and their calculated organic mass to organic carbon $(\mathrm{OM}: \mathrm{OC})$ ratio, their hydrogen to carbon $(\mathrm{H}: \mathrm{C})$ ratio, and their oxygen to carbon $(\mathrm{O}: \mathrm{C})$ ratio. $\mathrm{PMF}$ factors are hydrocarbonlike organic aerosol (HOA), nitrogen-containing organic aerosol (NOA), less-oxidized organic aerosol (LO-OA), more-oxidized organic aerosol (MO-OA), biomass burning organic aerosol (BBOA), and regional oxidized organic aerosol (OOA-Reg).

\begin{tabular}{lrrr}
\hline PMF factor & OM : OC & $\mathrm{H}: \mathrm{C}$ & $\mathrm{O}: \mathrm{C}$ \\
\hline HOA & 1.25 & 1.89 & 0.07 \\
NOA & 1.69 & 1.38 & 0.4 \\
LO-OA & 1.74 & 1.34 & 0.47 \\
MO-OA & 2.15 & 1.16 & 0.78 \\
BBOA & 1.56 & 1.47 & 0.32 \\
OOA-Reg & 1.85 & 1.54 & 0.52 \\
\hline
\end{tabular}

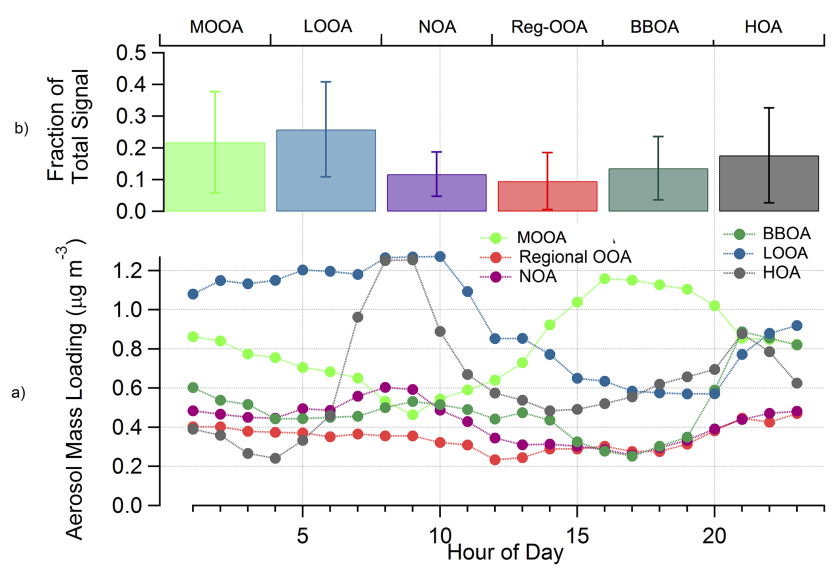

Figure 6. The diurnal profiles (a) and concentration and standard deviation of the six resolved aerosol factors (b).

ods (Fig. 6a). This is not the general behavior demonstrated in most studies for the NOA factor, although a similar NOA factor has been previously measured in the Po Valley, Italy (Saarikoski et al., 2012). This behavior was confirmed by examining HT periods, with an increase of $1.3 \times$ and $1.9 \times$ for NOA and HOA concentrations, respectively, during HT periods. While many of the defined N-containing peaks were adjacent to or in-between those of larger hydrocarbons or of other organics, only $\mathrm{N}$-containing peaks whose fitting significantly reduced the residual mass at each unit mass were fit (Fig. S8). Additionally, and when possible, the w-ToF (high resolution, non-quantitative) mode data were examined to determine if the $\mathrm{N}$-containing peak was resolved enough from neighboring peaks for certain identification.

In Fig. 7, the time series of each factor are shown with oxalate $\left(\mathrm{C}_{2} \mathrm{O}_{4}^{2-}\right.$, a marker for aged and oxidized organic aerosol), sulfates, and levoglucosan (a marker for biomass burning) measurements from filter samples. Table 2 summarizes the $R^{2}$ values between key tracer species and the resolved aerosol factors. The two main factors resolved, in terms of mass concentration, were the OOA factors with
Table 2. Correlation between AMS organic PMF factors and other tracer species, from filter samples (oxalate, levoglucosan), AMS data (sulfate), and MAAP data (BC). PMF factors are hydrocarbonlike organic aerosol (HOA), nitrogen-containing organic aerosol (NOA), less-oxidized organic aerosol (LO-OA), more-oxidized organic aerosol (MO-OA), biomass burning organic aerosol (BBOA), and regional oxidized organic aerosol (OOA-Reg).

\begin{tabular}{lrrrr}
\hline PMF FACTOR & $\begin{array}{r}\text { Oxalate } \\
(N=53)\end{array}$ & $\begin{array}{r}\mathrm{BC}^{\mathrm{a}} \\
(N=3928)\end{array}$ & $\begin{array}{r}\text { Levoglucosan } \\
(N=38)\end{array}$ & $\begin{array}{r}\text { Sulfate } \\
(N=3328)^{\mathrm{b}}\end{array}$ \\
& $R^{2}$ & $R^{2}$ & $R^{2}$ & $R^{2}$ \\
\hline HOA & 0.01 & 0.58 & 0.12 & 0.004 \\
BBOA & 0.04 & 0.05 & 0.65 & 0.005 \\
MO-OA & 0.50 & 0.01 & 0.02 & 0.54 \\
LO-OA & 0.32 & 0.01 & 0.08 & 0.07 \\
NOA & 0.01 & 0.09 & 0.12 & 0.06 \\
OOA-Reg & 0.62 & 0.02 & 0.01 & 0.65 \\
\hline a BC data smoothed to remove underestimated BC concentrations during periods of high filter
\end{tabular}

loading (Hyvärinen et al., 2013). ${ }^{\mathrm{b}} R^{2}$ value calculated after initial high $\mathrm{SO}_{4}$ period.

opposite diurnal trends, MO-OA and LO-OA. The concentration of MO-OA rose as the aerosol number-weighted geometric mode diameter rose, also indicative of increasing aerosol age/coagulation. The LO-OA factor resembled a semi-volatile oxidized organic aerosol factor reported by Docherty et al. (2008) measured during the Study of Organic Aerosols (SOAR) project in Riverside, CA, which was also found to decrease during the afternoon as temperature and photochemical processing increased. The chemical differences between these two spectra are shown in Fig. S10 and described in the Supplement. The increase in MO-OA concentration occurred both as the PTR-MS isoprene signal was increasing (also a temperature-related process) and as the 9-carbon aromatic : benzene $\left(\mathrm{C}_{9} \mathrm{H}_{13}^{+}: \mathrm{C}_{6} \mathrm{H}_{7}^{+}\right)$VOC ratio was at its minimum (related to photochemical age of air mass; Parrish et al., 2007). Thus, the increase MO-OA could be linked to photochemical aging of vehicular emissions during the day and/or increasing biogenic VOC emissions and their subsequent photochemical aging and condensation into aerosol form.

The BBOA factor was found to correlate with levoglucosan $\left(R^{2}=0.65, n=38\right)$; while significant levels of biomass burning from wood-burning stoves and other combustion-related heating are known to affect the Grenoble Valley in winter, such a large contribution during this season is surprising. Likely the PMF-resolved BBOA factor was somewhat mixed with emissions with close spectral signature (vehicular emissions or potentially cooking aerosol emissions). Episodic local yard-waste burning could also have contributed to the bulk aerosol spectrum, as spikes in the BBOA concentration do not appear to correlate with a particular wind direction (Fig. S9). The ratio of levoglucosan : BBOA is quite low (0.03); however, it is within the order of magnitude of previously reported measurements (e.g., 0.06; Aiken et al., 2009). Additionally, the higher levels of oxidants found in the atmosphere in the summer could cause 


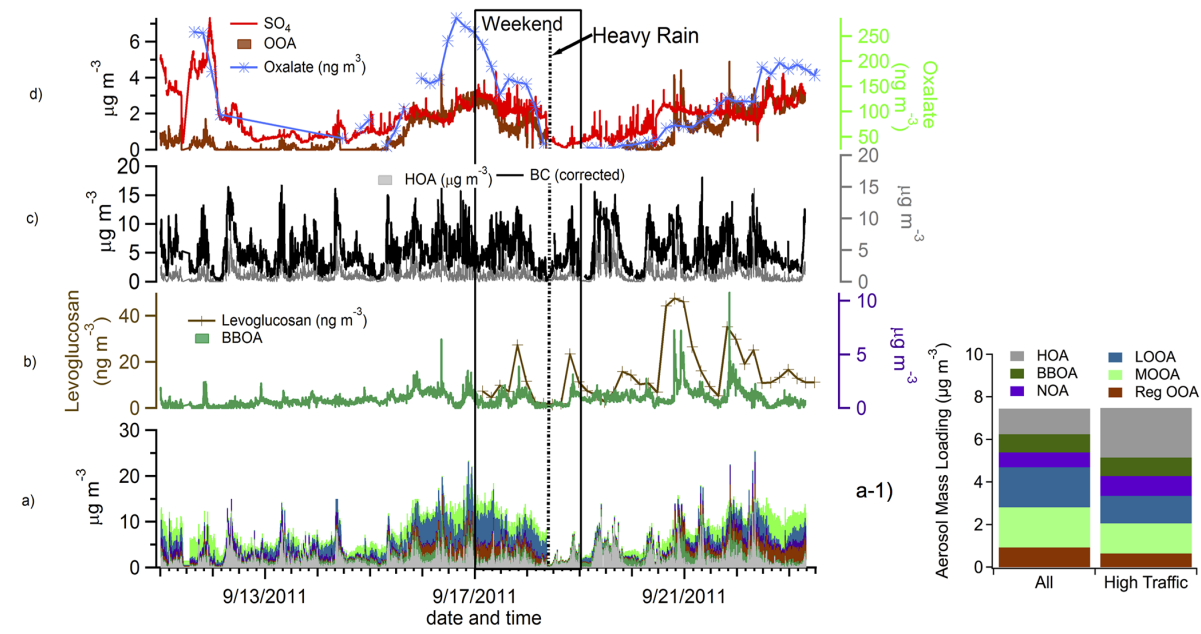

Figure 7. The time series of the six-factor PMF solution (a); the resolved BBOA factor time series concentration (right axis, b), and offline levoglucosan measurements (left axis, b); the resolved HOA factor time series concentration and BC (right axis, c); HR-ToF-AMS-measured $\mathrm{SO}_{4}$ and the resolved regional OOA factor (left axis, $\mathbf{d}$ ) and offline oxalate measurements (right axis, $\mathbf{d}$ ). The inset (a-1) shows the calculated mass contribution during all (left) and high-traffic (right) periods of each resolved PMF factor (same color legend for a and a-1).

a faster degradation of levoglucosan in the atmosphere after emission (Hennigan et al., 2010). Thus, the BBOA concentrations reported here shall be considered as an upper limit of the biomass burning contribution.

Oxalate and OOA-Reg covaried with an $R^{2}$ of 0.62 $(n=53)$. Regional OOA was identified as such due to its low temporal variation, its correlation with $\mathrm{SO}_{4}$, and a low correlation with wind direction (Fig. S8). This factor was removed from the atmosphere during periods of rain and experienced a slow recovery afterwards. At the beginning of the experiment (11-13 September), regional OOA and $\mathrm{SO}_{4}$ did not correspond; however, during the middle and end of the campaign, temporal variations of the regional $\mathrm{OOA}$ and $\mathrm{SO}_{4}$ corresponded fairly well $\left(R^{2}=0.65, n=3328\right)$. The reason for the initial high $\mathrm{SO}_{4}$ and low regional OOA is unclear from the data set as is; however, MO-OA and $\mathrm{SO}_{4}$ also had similar time series trends $\left(R^{2}=0.50, n=3328\right)$ and MO-OA was high at the beginning of the campaign. The closeness of the two spectra's composition, as well as the nature of the aerosol type (not from a specific source but rather aged bulk organic aerosol), in which variations would logically occur, may have led to the imprecise separation of these two factor types.

Of the factors resolved, the HOA factor had the lowest $\mathrm{O}: \mathrm{C}$ ratio $(0.07)$ and a good $\left(R^{2}=0.58, n=3928\right)$ correlation with $\mathrm{BC}$ concentration. The mass spectrum of the resolved HOA factor highly resembled $\left(R^{2}>0.95, n=100\right)$ previously resolved HOA factors and direct AMS measurements of diesel and gasoline emissions (Mohr et al., 2009; Zhang et al., 2005). HOA was not the largest average contributor to the bulk measured aerosol mass over the campaign period, despite the fact that these measurements were conducted $15 \mathrm{~m}$ from a major highway. The relative size of each type of particle (primary, or HOA, and OOA) likely played a major role in the relative mass concentrations of each factor (Fig. S11 and discussion), and the higher increase above background of particle number versus particle mass found in this study agrees with previous studies (Karner et al., 2010; Sun et al., 2012). The variability of each factor over the campaign was high as, unlike measurements in more rural areas, the proximity to a primary aerosol source (highway) and to an urban center (Grenoble) as well as large green spaces (the Alps) allowed the full range of aged and locally transported aerosol to be observed at this station.

\subsubsection{Fossil and modern carbon}

A source of uncertainty in the global particulate emissions of vehicles is the formation of SOA from gas-phase emissions and the aging of POA. To discriminate between the relative concentration of modern and fossil carbon, and thus potentially discriminate between OOA from vehicular sources and from modern sources, daily filter samples were collected at the sampling site and ${ }^{14} \mathrm{C}$ radiocarbon measurements were performed. From these measurements, the percentage of modern carbon from TC $(\mathrm{OC}+\mathrm{EC})$ was calculated. Modern carbon varied from 15 to $36 \%$ of the total aerosol carbon, a significant portion of the measured carbon considering the close proximity of the measurements to fossil carbon sources. In France, the contribution of biofuel was about 7 and $5 \%$ for diesel and gasoline fuel, respectively, in 2011 (UFIP, Union Française des Industries Petrolières, 2011) and cannot explain this relatively high proportion of modern carbon observed in the particulate matter. This is similar to findings shown in Hodzic et al. (2010), Minguillón et al. (2011), and El Haddad et al. (2013) which indicate that modern carbon is often a significant portion of the car- 
bonaceous fraction of PM, even in cities with high vehicular emissions (e.g., Mexico City, Barcelona, or Marseille).

As radiocarbon measurements have been performed through a thermal approach (combustion of the samples at $850^{\circ} \mathrm{C}$ ), we consider in the following section EC measured by the thermal-optical method. As shown in Fig. S12, EC and $\mathrm{BC}$ agree well at low mass loadings but have a wider scatter in the data at higher mass loadings. The calculation of BC (measured by the MAAP) using an absorption crosssection is imprecise and, at high loadings of $\mathrm{BC}$, may underor overestimate this mass loading. Figure S12 shows a comparison between the MAAP (BC) and thermal measurement (EC) data, with a 1:1 line. As the thermal-optical analysis of EC is a more direct analysis, EC was chosen to be used in this calculation.

Assuming that the majority of EC was traffic-related and thus from fossil origin, the concentration of modern organic carbon and fossil organic carbon was then calculated. While evidence for the presence of biomass burning aerosol was measured at the field site, the main source of EC was likely diesel exhaust. Figure 8 shows the fraction of EC and OC, HOA, and a partitioning between fossil and modern carbon. In Fig. 8a, a rough calculation was performed to determine the concentration of non-primary fossil organic carbon. For a first estimate, all EC was assumed to be fossil in origin. Additionally, the HOA aerosol was also assumed to be vehicular, and thus fossil, in origin. The HOA factor concentration has been divided by its OM : OC ratio to remove any non-carbon mass (HOA C, calculated from the elemental formulas of the PMF factor mass spectra; Aiken et al., 2008). Both EC and HOA C had high ( $R^{2}=0.89$ and 0.85 , respectively, $n=10$ ) correlations with the fossil $\mathrm{C}$ mass, which supported a largely fossil source for these two species. The remaining fossil organic carbon mass after subtraction was then assumed to be from non-primary sources (in light blue).

This calculation provided a lower estimate of the amount of fossil carbon contributing to SOA mass and involves several assumptions and potential sources of error. Sources of error in this calculation include error in the PMF resolution of primary (HOA) organic aerosol spectra and error in the calculated OM : OC ratio of this factor species, biodiesel vehicular emissions contributing modern carbon to measured HOA, and biomass burning aerosol contributing modern carbon to measured EC.

As the measured HOA: EC ratio was in line with previous measurements in high-diesel environments, HOA concentrations did not appear to be significantly over- or underestimated. Up to $7 \%$ of fuel use in France was biodiesel; thus, part of the HOA concentration could be from modern sources. While research has shown that the use of biodiesel fuels reduces the overall primary particulate matter emissions (Cheung et al., 2010), biodiesel could still be a modern carbon contributor to OC and EC mass. Additionally, although the concentration of BBOA was generally low (a campaign average of $0.34 \pm 0.23 \mu \mathrm{g} \mathrm{m}^{-3}$ ) and the ratio of BBOA : EC

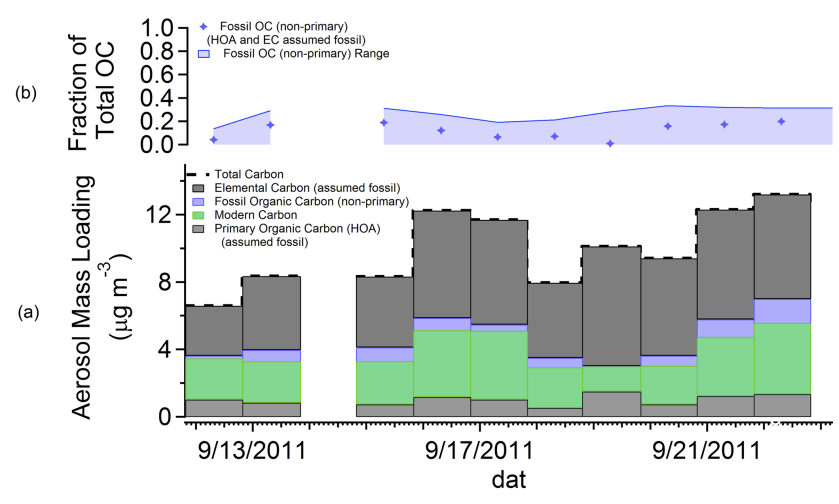

Figure 8. Measured EC and OC, with calculated contribution of non-primary fossil organic carbon (assuming $100 \%$ fossil EC and HOA, a) and assuming partial modern organic carbon EC and HOA contribution (b). The possible fossil OOA (light blue) was calculated by the subtraction of HOA from the fossil-OC fraction (assuming HOA either all fossil, a, or $95 \%$ fossil, b), and EC either all fossil (a) or $5 \%+$ BBOA/3 modern (b).

has been found to be on the order of 3-4 in other areas of France (Crippa et al., 2013), some contribution to EC from biomass burning may have been present at the measurement site. In Fig. 8b, a range of fossil non-primary organic carbon, normalized to total measured organic carbon, is presented. For the upper limit of this range, HOA C and EC were considered to be $95 \%$ fossil and $5 \%$ modern ( $7 \%$ biodiesel fuel use and an estimated $25 \%$ reduction in particulate emissions from biodiesel fuel). Also for this upper limit, the calculated concentration of BBOA was divided by 3 and used to calculate possible modern EC from biomass burning (Crippa et al., 2013).

Total organic carbon concentration appeared to be more driven by processed/aged OOA concentrations than by primary emissions. During the period with the highest organic concentrations (15-17 September), most of the non-HOA carbon measured was modern carbon. Also during this time period, the winds were slightly more southerly and $\mathrm{SO}_{4}$ and OOA concentrations increased, which could indicate a more regional contribution to the measured air mass during this time. After a period of heavy rain on 19 September, almost none of the non-HOA organic carbon was fossil; however, this also coincided with a period of increased BBOA, which may have contributed to modern-EC emissions and thus an underestimate of fossil-OC emissions (Fig. 7). At other times during the campaign, HOA concentrations alone could not adequately explain all of the measured fossil organic carbon and additional sources of fossil organic carbon (such as photochemical reactions forming aerosol from vehicular VOC emissions) that would be needed. Additionally, the origin of the NOA factor remains unclear; if fossil in origin, it could explain part of the non-HOA organic fossil carbon measured at the site, further reducing the OOA fossil-C (at times to al- 
most 0 ). Overall, throughout the campaign the majority of OOA observed was most probably modern in origin.

The high levels of modern carbon OOA suggested that biogenic compounds had a large effect on the overall aerosol population in this location, even directly adjacent to a large anthropogenic emission source (i.e., traffic). Interaction between anthropogenic oxidants and biogenic VOCs (or BVOCs) has been found to increase the formation of SOA (Chameides et al., 1988; Goldstein et al., 2009; Shilling et al., 2013), isoprene oxidation reactions leading towards SOA have been shown to vary depending on the level of $\mathrm{NO}_{x}$ (Chen et al., 2014; Kroll et al., 2005; Ng et al., 2007; Xu et al., 2014), and likely BVOC concentrations were greater and the aromatic VOC concentrations were lower in the wider Grenoble Valley.

\subsubsection{Differences between diesel-heavy and gasoline-heavy near-roadway measurements}

Older diesel vehicles have been shown to emit both higher levels of PM, particularly $\mathrm{BC}$, and higher levels of $\mathrm{NO}_{x}$. Indeed, high concentrations of $\mathrm{NO}_{x}$ were measured at the field site, up to $450 \mathrm{ppbv}\left(\mathrm{NO}+\mathrm{NO}_{2}\right)$ for $15 \mathrm{~min}$ averaged measurements. $\mathrm{NO}_{2}$ levels exceeded the 100 ppbv European hourly limit almost every morning. The campaign average for $\mathrm{NO}_{2}$ was $94 \pm 64$ ppbv. For comparison, at a measurement site adjacent to a major highway in New York, Sun et al. (2012) measured an average of $48 \pm 30 \mathrm{ppbv} \mathrm{NO}_{2}$, about half that of this campaign's average, with 15 min average peaks ranging from 100 to $300 \mathrm{ppbv}$ during high-traffic periods. The hourly traffic concentrations at each site were close (approximately 10000 vehicles $\mathrm{h}^{-1}$ reported during the Sun et al. (2012) measurement periods compared to approximately 8000 vehicles $\mathrm{h}^{-1}$ observed during daylight driving hours on Grenoble's highway); thus, increased $\mathrm{NO}_{x}$ cannot be explained by increased traffic. Rather, increased diesel fuel use is a very likely hypothesis.

High levels of $\mathrm{BC}$ were also measured in this work. A comparison of the HOA : $\mathrm{BC}$ ratio from this study and from previously reported field studies is shown in Fig. 9a. As expected, since the French fleet includes a much higher percentage of diesel cars with increased $\mathrm{BC}$ emissions, this ratio was significantly lower than that reported for an urban downwind site in Pittsburgh (1.41, Zhang et al., 2005), a highwayadjacent site in New York (1.02, Sun et al., 2012), an urban/highway site in Ontario (0.7-1.1, Stroud et al., 2012), a rural site in northwest England (1.61-1.91, Liu et al., 2006), and an urban site in Zurich, Switzerland (1.1, Lanz et al., 2007). As for measurements in France, a study in an urban site in Paris observed a HOA : BC ratio of 0.61 (Crippa et al., 2013); this site was most probably influenced by a vehicle fleet similar to Grenoble's, but measurements were collected during winter (lower temperatures) and within Paris (increased urban emissions). Tailpipe measurements of Euro 4 diesel and gasoline-powered vehicles (a Renault Kangoo and

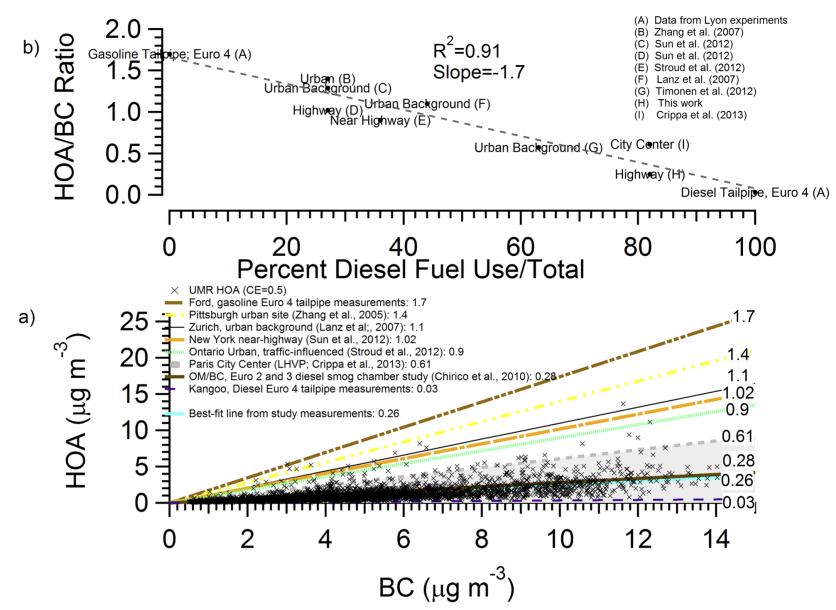

Figure 9. Calculated HOA and measured $\mathrm{BC}$ concentrations from the campaign and HOA: BC ratios from previous field campaigns. Grey area is shaded to include a diesel-only environment and two French HOA : BC ratios: from Crippa et al. (2013) and from this study (a). The HOA : BC ratio from various literature sources versus percent diesel fuel use out of total fuel use for the country of study (b).

a Ford Ka, respectively) at IFSTTAR (Institut Français des Sciences et Technologies des Transports, de l'Aménagement et des Réseaux) performed during this PM-DRIVE research program also show a much higher HOA : BC ratio for gasoline vehicles versus diesel vehicles (unpublished data). This was due to much higher $\mathrm{BC}$ emissions from the diesel vehicle, as opposed to higher HOA emissions from the gasoline vehicle.

Similarly, the HOA factor measured near Grenoble resembled that measured by Sun et al. (2012) in a high-gasoline environment next to a highway in New York, both in absolute concentration and chemical composition; thus, an increase in $\mathrm{BC}$ emissions (from diesel) rather than a reduction in $\mathrm{HOA}$ : vehicle number was likely the cause of our low HOA : BC ratio.

The change in HOA:BC ratio as a function of the diesel : gasoline fuel use (Road sector, World Bank, 2011) is shown in Fig. 9b. A decrease in HOA : BC with an increase in percent diesel is clearly observable with a strong correlation ( $\left.R^{2}=0.85, n=10\right)$, despite the many different factors possibly influencing BC and HOA concentrations at each location (e.g., local aerosol sources, meteorology). Such a linear relationship between HOA : $\mathrm{BC}$ and diesel percentage is very interesting but not necessarily expected, since the emission factors of HOA + BC differ significantly between diesel and gasoline cars, especially for pre-EURO 5 vehicles.

Additionally, an AMS factor with a diurnal pattern peaking during rush hour and with $\mathrm{N}$-containing peaks was observed (see Sect. 3.3). Saarikoski et al. (2012) found a similar amine-containing NOA factor in measurements taken in the Po Valley (Italy) that also had a strong diurnal pattern. 
However, their NOA factor was attributed to marine influence due to a correlation with methanesulfonic acid (MSA) (Saarikoski et al., 2012), although it is possible that MSA was from the local industrial use of dimethyl sulfoxide as a solvent and had a higher $\mathrm{H}: \mathrm{C}$ ratio (1.91) than the factor resolved from this data set (1.38). Like France, Italy has a large percentage of diesel fuel consumption (71\%; World Bank, 2011). Aiken et al. (2009) and Sun et al. (2011) also resolved $\mathrm{N}$-containing OA factors from data measured in Mexico City and New York, respectively, but did not observe a similar diurnal pattern. In the PTR-MS mass spectra results obtained from Euro 5 vehicle emission smog chamber studies, Hellebust et al. (2013) found higher nitrogen-containing emissions from fresh and aged diesel mass than from fresh and aged gasoline mass spectra (e.g., peaks such as $\mathrm{CH}_{4} \mathrm{NO}_{2}^{+}$). Similar nitrogen-containing VOC peaks were found by Inomata et al. (2013) in diesel exhaust. Thus, diesel-related emissions could possibly be the source for the observed NOA factor, although no significant correlation between this factor and other vehicular emissions, such as BC, was found. More detail on the NOA factor can be found in the Supplement and Fig. S13.

Finally, only small amounts OOA measured at the field site were calculated to contain fossil OC. Work by Bahreini et al. (2010) found that much of the measured SOA in the Los Angeles Valley was from gasoline passenger cars, not from diesel trucks, and perhaps the relatively low concentration of gasoline vehicles on the road in France is related to the low concentration of fossil OOA.

\section{Conclusions}

During this campaign, highly time-resolved particle and gas-phase chemical composition and concentration measurements were obtained alongside parallel traffic data of the speed, fluxes, vehicle type, and fuel type of passing cars on a highway in the Grenoble Valley. An analysis of the local primary (traffic) aerosol and the more regional, aged secondary organic aerosol was performed for the $\mathrm{PM}_{1}$ fraction observed by the HR-ToF-AMS. The PMF model was run on the highresolution HR-ToF-AMS aerosol data and six factors were resolved from the bulk aerosol data: (1) an HOA factor related to traffic, (2) a BBOA factor, (3) a regional OOA factor which covaried with sulfate, (4) a MO-OA factor increasing in concentration during sunny afternoons, (5) a LO-OA factor with the opposite diurnal pattern as MO-OA likely due to gas-particle phase partitioning and photochemical processing, and (6) an NOA factor with a diurnal pattern similar to that of HOA and traffic peaks.

The resolved mass spectrum for the HOA factor was chemically similar to mass spectra from both gasoline and diesel-emitted organic carbon and previously resolved HOA factors in high-gasoline environments; however, the HOA : BC ratio measured was low $(<0.3)$ throughout the campaign. This ratio agrees with previously reported HOA : BC ratios in high-diesel environments and from direct measurements of diesel emissions in smog chamber and tailpipe measurement studies. The fraction of diesel-powered vehicles on the road appeared to control, to some extent, this ratio. Diesel also influenced local $\mathrm{NO}_{x}$ concentrations, as the measured $\mathrm{NO}_{x}$ was 2 times higher than concentrations near a similarly trafficked highway in New York, USA.

While high levels of both black carbon $\left(5 \pm 3 \mu \mathrm{g} \mathrm{m}^{-3}\right)$ and organic aerosol $\left(8 \pm 4 \mu \mathrm{g} \mathrm{m}^{-3}\right)$ were measured, only $20 \%$ of the total organic mass signal could be attributed to primary vehicular emissions (i.e., HOA) when examined. Significant amounts of modern organic carbon were also measured, and fossil carbon appeared to contribute only a small amount to the measured OOA. Although $\mathrm{NO}_{x}$ and VOCs emitted by diesel and gasoline engines, respectively, may have influenced SOA formation in the Grenoble Valley, the majority of OOA measured was modern in origin, even adjacent to a major source of fossil carbon. Whether this is due to a lower overall gas plus particle emission of diesel vehicles, the lack of aromatic compounds in diesel VOC emissions, high $\mathrm{NO}_{x}$ reducing the efficiency of vehicular VOC to SOA formation mechanisms, an acceleration of BVOC to biogenic aerosol formation in the presence of vehicular emissions, or simply the more global source and higher efficiency of BVOC to SOA reactions is unclear, but, in a high-diesel environment, SOA OOA from fossil-fuel carbon was only a small source of the measured OOA, while modern C-containing OOA dominated the organic aerosol mass in the fine fraction of $\mathrm{PM}_{1}$.

\section{The Supplement related to this article is available online at doi:10.5194/acp-15-4373-2015-supplement.}

Acknowledgements. This work was supported by the French Environment and Energy Management Agency (ADEME, grant number 1162C0002). The authors gratefully acknowledge the NOAA Air Resources Laboratory (ARL) for the provision of the HYSPLIT transport and dispersion model (http://www.ready.noaa.gov) used in this publication. We also gratefully acknowledge Air RhôneAlpes staff (particularly Yann Pellan) for their support during the campaign, Y. Sun and Q. Zhang for providing near-highway aerosol data from their paper (Sun et al., 2012) for comparison with these measurements, and the MASSALYA instrumental platform (Aix-Marseille Université, http://lce.univ-amu.fr) for the analysis and measurements used in this publication. Finally, the authors would like to acknowledge and thank the two anonymous reviewers who provided constructive advice on the formation of the final paper.

Edited by: J. Liggio 


\section{References}

Aiken, A. C., Decarlo, P. F., Kroll, J. H., Worsnop, D. R., Huffman, J. A., Docherty, K. S., Ulbrich, I. M., Mohr, C., Kimmel, J. R., Sueper, D., Sun, Y., Zhang, Q., Trimborn, A., Northway, M., Ziemann, P. J., Canagaratna, M. R., Onasch, T. B., Alfarra, M. R., Prevot, A. S. H., Dommen, J., Duplissy, J., Metzger, A., Baltensperger, U., and Jimenez, J. L.: O / C and OM / OC ratios of primary, secondary, and ambient organic aerosols with high-resolution time-of-flight aerosol mass spectrometry, Environ. Sci. Technol., 42, 4478-4485, 2008.

Aiken, A. C., Salcedo, D., Cubison, M. J., Huffman, J. A., DeCarlo, P. F., Ulbrich, I. M., Docherty, K. S., Sueper, D., Kimmel, J. R., Worsnop, D. R., Trimborn, A., Northway, M., Stone, E. A., Schauer, J. J., Volkamer, R. M., Fortner, E., de Foy, B., Wang, J., Laskin, A., Shutthanandan, V., Zheng, J., Zhang, R., Gaffney, J., Marley, N. A., Paredes-Miranda, G., Arnott, W. P., Molina, L. T., Sosa, G., and Jimenez, J. L.: Mexico City aerosol analysis during MILAGRO using high resolution aerosol mass spectrometry at the urban supersite (T0) - Part 1: Fine particle composition and organic source apportionment, Atmos. Chem. Phys., 9, 6633-6653, doi:10.5194/acp-9-6633-2009, 2009.

Bahreini, R., Middlebrook, A. M., de Gouw, J. A., Warneke, C., Trainer, M., Brock, C. A., Stark, H., Brown, S. S., Dube, W. P., Gilman, J. B., Hall, K., Holloway, J. S., Kuster, W. C., Perring, A. E., Prevot, A. S. H., Schwarz, J. P., Spackman, J. R., Szidat, S., Wagner, N. L., Weber, R. J., Zotter, P., and Parrish, D. D.: Gasoline emissions dominate over diesel in formation of secondary organic aerosol mass, Geophys. Res. Lett., 39, L06805, doi:10.1029/2011GL050718, 2012.

Birch, M. E. and Cary, R. A.: Elemental Carbon-Based Method for Monitoring Occupational Exposures to Particulate Diesel Exhaust, Aerosol Sci. Technol., 25, 221-241, 1996.

Bond, T. C., Doherty, S. J., Fahey, D. W., Forster, P. M., Berntsen, T., DeAngelo, B. J., Flanner, M. G., Ghan, S., Kärcher, B., Koch, D., Kinne, S., Kondo, Y., Quinn, P. K., Sarofim, M. C., Schultz, M. G., Schulz, M., Venkataraman, C., Zhang, H., Zhang, S., Bellouin, N., Guttikunda, S. K., Hopke, P. K., Jacobson, M. Z., Kaiser, J. W., Klimont, Z., Lohmann, U., Schwarz, J. P., Shindell, D., Storelvmo, T., Warren, S. G., and Zender, C. S.: Bounding the role of black carbon in the climate system: A scientific assessment, J. Geophys. Res. Atmos., 118, 5380-5552, doi:10.1002/jgrd.50171, 2013.

Broderick, B. and Marnane, I.: A comparison of the C2-C9 hydrocarbon compositions of vehicle fuels and urban air in Dublin, Ireland, Atmos. Environ., 36, 975-986, doi:10.1016/S13522310(01)00472-1, 2002.

Brugge, D., Durant, J. L., and Rioux, C.: Near-highway pollutants in motor vehicle exhaust: a review of epidemiologic evidence of cardiac and pulmonary health risks, Environ. Health, 6, 23, doi:10.1186/1476-069X-6-23, 2007.

Carlton, A. G., Wiedinmyer, C., and Kroll, J. H.: A review of Secondary Organic Aerosol (SOA) formation from isoprene, Atmos. Chem. Phys., 9, 4987-5005, doi:10.5194/acp-9-4987-2009, 2009.

Cavalli, F., Viana, M., Yttri, K. E., Genberg, J., and Putaud, J.-P.: Toward a standardised thermal-optical protocol for measuring atmospheric organic and elemental carbon: the EUSAAR protocol, Atmos. Meas. Tech., 3, 79-89, doi:10.5194/amt-3-79-2010, 2010.
Chameides, W., Lindsay, R., Richardson, J., and Kiang, C.: The role of biogenic hydrocarbons in urban photochemical smog: Atlanta as a case study, Science, 241, 1473-1475, doi:10.1126/science.3420404, 1988.

Chen, J., Zhao, C. S., Ma, N., and Yan, P.: Aerosol hygroscopicity parameter derived from the light scattering enhancement factor measurements in the North China Plain, Atmos. Chem. Phys., 14, 8105-8118, doi:10.5194/acp-14-8105-2014, 2014.

Cheung, K. L., Ntziachristos, L., Tzamkiozis, T., Schauer, J. J., Samaras, Z., Moore, K. F., and Sioutas, C.: Emissions of Particulate Trace Elements, Metals and Organic Species from Gasoline, Diesel, and Biodiesel Passenger Vehicles and Their Relation to Oxidative Potential, Aerosol Sci. Technol., 44, 500-513, doi:10.1080/02786821003758294, 2010.

Chirico, R., DeCarlo, P. F., Heringa, M. F., Tritscher, T., Richter, R., Prévôt, A. S. H., Dommen, J., Weingartner, E., Wehrle, G., Gysel, M., Laborde, M., and Baltensperger, U.: Impact of aftertreatment devices on primary emissions and secondary organic aerosol formation potential from in-use diesel vehicles: results from smog chamber experiments, Atmos. Chem. Phys., 10, 11545-11563, doi:10.5194/acp-10-11545-2010, 2010.

Crippa, M., DeCarlo, P. F., Slowik, J. G., Mohr, C., Heringa, M. F., Chirico, R., Poulain, L., Freutel, F., Sciare, J., Cozic, J., Di Marco, C. F., Elsasser, M., Nicolas, J. B., Marchand, N., Abidi, E., Wiedensohler, A., Drewnick, F., Schneider, J., Borrmann, S., Nemitz, E., Zimmermann, R., Jaffrezo, J.-L., Prévôt, A. S. H., and Baltensperger, U.: Wintertime aerosol chemical composition and source apportionment of the organic fraction in the metropolitan area of Paris, Atmos. Chem. Phys., 13, 961-981, doi:10.5194/acp-13-961-2013, 2013.

DeCarlo, P. F., Kimmel, J. R., Trimborn, A., Northway, M. J., Jayne, J. T., Aiken, A. C., Gonin, M., Fuhrer, K., Horvath, T., Docherty, K. S., Worsnop, D. R., and Jimenez, J. L.: Field-Deployable, high-resolution, time-of-flight aerosol mass spectrometer, Anal. Chem., 78, 8281-8289, doi:8410.1029/2001JD001213. 2006.

Docherty, K. S., Stone, E. A., Ulbrich, I. M., DeCarlo, P. F., Snyder, D. C., Schauer, J. J., Peltier, R. E., Weber, R. J., Murphy, S. M., Seinfeld, J. H., Grover, B. D., Eatough, D. J., and Jimenez, J. L.: Apportionment of Primary and Secondary Organic Aerosols in Southern California during the 2005 Study of Organic Aerosols in Riverside (SOAR-1), Environ. Sci. Technol., 42, 7655-7662, doi:10.1021/es8008166, 2008.

El Haddad, I., Marchand, N., Dron, J., Temime-Roussel, B., Quivet, E., Wortham, H., Jaffrezo, J. L., Baduel, C., Voisin, D., Besombes, J. L., and Gille, G.: Comprehensive primary particulate organic characterization of vehicular exhaust emissions in France, Atmos. Environ., 43, 6190-6198, doi:10.1016/j.atmosenv.2009.09.001, 2009.

El Haddad, I., Marchand, N., Wortham, H., Piot, C., Besombes, J.L., Cozic, J., Chauvel, C., Armengaud, A., Robin, D., and Jaffrezo, J.-L.: Primary sources of $\mathrm{PM}_{2.5}$ organic aerosol in an industrial Mediterranean city, Marseille, Atmos. Chem. Phys., 11, 2039-2058, doi:10.5194/acp-11-2039-2011, 2011.

El Haddad, I., D’Anna, B., Temime-Roussel, B., Nicolas, M., Boreave, A., Favez, O., Voisin, D., Sciare, J., George, C., Jaffrezo, J.-L., Wortham, H., and Marchand, N.: Towards a better understanding of the origins, chemical composition and aging of oxygenated organic aerosols: case study of a Mediterranean industri- 
alized environment, Marseille, Atmos. Chem. Phys., 13, 78757894, doi:10.5194/acp-13-7875-2013, 2013.

Favez, O., El Haddad, I., Piot, C., Boréave, A., Abidi, E., Marchand, N., Jaffrezo, J.-L., Besombes, J.-L., Personnaz, M.-B., Sciare, J., Wortham, H., George, C., and D'Anna, B.: Inter-comparison of source apportionment models for the estimation of wood burning aerosols during wintertime in an Alpine city (Grenoble, France), Atmos. Chem. Phys., 10, 5295-5314, doi:10.5194/acp-10-52952010, 2010.

Gentner, D. R., Isaacman, G., Worton, D. R., Chan, A. W. H., Dallmann, T. R., Davis, L., Liu, S., Day, D. A., Russell, L. M., Wilson, K. R., Weber, R., Guha, A., Harley, R. A., and Goldstein, A. H.: Elucidating secondary organic aerosol from diesel and gasoline vehicles through detailed characterization of organic carbon emissions, P. Natl. Acad. Sci. USA, 109, 18318-18323, doi:10.1073/pnas.1212272109, 2012.

Goldstein, A. H., Koven, C. D., Heald, C. L., and Fung, I. Y.: Biogenic carbon and anthropogenic pollutants combine to form a cooling haze over the southeastern United States, P. Natl. Acad. Sci. USA, 106, 8835-8840, doi:10.1073/pnas.0904128106, 2009.

Graus, M., Muller, M., and Hansel, A.: High resolution PTR-TOF: Quantification and formula confirmation of VOC in real time, J. Am. Soc. Mass Spectr., 21, 1037-1044, 2010.

Hellebust, S., Temime-Roussel, B., Bertrand, A., Platt, S. M., El Haddad, I., Pieber, S., Zardini, A. A., Suarez-Bertoa, R., Slowik, J. G., Huang, R. J., Astorga, C., Prevot, A. S. H., and Marchand, N.: Comparison of Gasoline and Diesel Vehicles-Emission Factors of Volatile Organic Compounds from EURO5 Diesel and Gasoline Vehicles and Their Potential Integrated Influence on Air Quality, Am. Assoc. Aerosol Res., p. 145, Fall 2013, Mt. Laurel, NJ, 2013.

Hennigan, C. J., Sullivan, A. P., Collett, J. L., and Robinson, A. L.: Levoglucosan stability in biomass burning particles exposed to hydroxyl radicals, Geophys. Res. Lett., 37, L09806, doi:10.1029/2010GL043088, 2010.

Herich, H., Gianini, M. F. D., Piot, C., Močnik, G., Jaffrezo, J.-L., Besombes, J.-L., Prévôt, A. S. H., and Hueglin, C.: Overview of the impact of wood burning emissions on carbonaceous aerosols and PM in large parts of the Alpine region, Atmos. Environ., 89, 64-75, doi:10.1016/j.atmosenv.2014.02.008, 2014.

Hodzic, A., Jimenez, J. L., Madronich, S., Canagaratna, M. R., DeCarlo, P. F., Kleinman, L., and Fast, J.: Modeling organic aerosols in a megacity: potential contribution of semi-volatile and intermediate volatility primary organic compounds to secondary organic aerosol formation, Atmos. Chem. Phys., 10, 5491-5514, doi:10.5194/acp-10-5491-2010, 2010.

Huffman, J. A., Jayne, J. T., Drewnick, F., Aiken, A. C., Onasch, T., Worsnop, D. R., and Jimenez, J. L.: Design, Modeling, Optimization, and Experimental Tests of a Particle Beam Width Probe for the Aerodyne Aerosol Mass Spectrometer, Aerosol Sci. Technol., 39, 1143-1163, doi:10.1080/02786820500423782, 2005.

Hyvärinen, A.-P., Vakkari, V., Laakso, L., Hooda, R. K., Sharma, V. P., Panwar, T. S., Beukes, J. P., van Zyl, P. G., Josipovic, M., Garland, R. M., Andreae, M. O., Pöschl, U., and Petzold, A.: Correction for a measurement artifact of the Multi-Angle Absorption Photometer (MAAP) at high black carbon mass concentration levels, Atmos. Meas. Tech., 6, 81-90, doi:10.5194/amt-681-2013, 2013.
Inomata, S., Tanimoto, H., Fujitani, Y., Sekimoto, K., Sato, K., Fushimi, A., Yamada, H., Hori, S., Kumazawa, Y., Shimono, A., and Hikida, T.: On-line measurements of gaseous nitroorganic compounds in diesel vehicle exhaust by proton-transferreaction mass spectrometry, Atmos. Environ., 73, 195-203, doi:10.1016/j.atmosenv.2013.03.035, 2013.

Jaffrezo, J. L., Davidson, C. I., Kuhns, H. D., Bergin, M. H., Hillamo, R., Maenhaut, W., Kahl, J. W., and Harris, J. M.: Biomass burning signatures in the atmosphere of central Greenland, J. Geophys. Res.-Atmos., 103, 31067-31078, 1998.

Jaffrezo, J.-L., Aymoz, G., and Cozic, J.: Size distribution of EC and $\mathrm{OC}$ in the aerosol of Alpine valleys during summer and winter, Atmos. Chem. Phys., 5, 2915-2925, doi:10.5194/acp-52915-2005, 2005.

Janssen, N. A. H.: World Health Organization, Regional Office for Europe and Joint WHO/Convention Task Force on the Health Aspects of Air Pollution: Health effects of black carbon, available at: http://www.euro.who.int/_data/assets/pdf_ file/0004/162535/e96541.pdf (last access: 28 June 2013), 2012.

Karner, A. A., Eisinger, D. S., and Niemeier, D. A.: NearRoadwayAir Quality: Synthesizing the Findings from RealWorld Data, Environ. Sci. Technol., 44, 5334-5344, 2010.

Kroll, J. H., Ng, N. L., Murphy, S. M., Flagan, R. C., and Seinfeld, J. H.: Secondary organic aerosol formation from isoprene photooxidation under high-NO $\mathrm{NO}_{x}$ conditions, Geophys. Res. Lett., 32, L18808, doi:10.1029/2005GL023637, 2005.

Lanz, V. A., Alfarra, M. R., Baltensperger, U., Buchmann, B., Hueglin, C., and Prévôt, A. S. H.: Source apportionment of submicron organic aerosols at an urban site by factor analytical modelling of aerosol mass spectra, Atmos. Chem. Phys., 7, 15031522, doi:10.5194/acp-7-1503-2007, 2007.

Lighty, J. S., Veranth, J. M., and Sarofim, A. F.: Combustion Aerosols: Factors Governing Their Size and Composition and Implications to Human Health, J. Air Waste Manage., 50, 15651618, doi:10.1080/10473289.2000.10464197, 2000.

Liu, L., Lacis, A. A., Carlson, B. E., Mishchenko, M. I., and Cairns, B.: Assessing Goddard Institute for Space Studies ModelE aerosol climatology using satellite and ground-based measurements: A comparison study, J. Geophys. Res., 111, D20212, doi:10.1029/2006JD007334, 2006.

Matthew, B. M., Middlebrook, A. M., and Onasch, T. B.: Collection Efficiencies in an Aerodyne Aerosol Mass Spectrometer as a Function of Particle Phase for Laboratory Generated Aerosols, Aerosol Sci. Technol., 42, 884-898, doi:10.1080/02786820802356797, 2008.

Minguillón, M. C., Perron, N., Querol, X., Szidat, S., Fahrni, S. M., Alastuey, A., Jimenez, J. L., Mohr, C., Ortega, A. M., Day, D. A., Lanz, V. A., Wacker, L., Reche, C., Cusack, M., Amato, F., Kiss, G., Hoffer, A., Decesari, S., Moretti, F., Hillamo, R., Teinilä, K., Seco, R., Peñuelas, J., Metzger, A., Schallhart, S., Müller, M., Hansel, A., Burkhart, J. F., Baltensperger, U., and Prévôt, A. S. H.: Fossil versus contemporary sources of fine elemental and organic carbonaceous particulate matter during the DAURE campaign in Northeast Spain, Atmos. Chem. Phys., 11, 12067-12084, doi:10.5194/acp-11-12067-2011, 2011.

Mohr, C., Huffman, J. A., Cubison, M. J., Aiken, A. C., Kenneth, S., Kimmel, J. R., Ulbrich, I. M., Hannigan, M., and Jimenez, J. L.: Characterization of Primary Organic Aerosol Emissions from Meat Cooking, Trash Burning, and Motor Vehicles with High- 
Resolution Aerosol Mass Spectrometry and Comparison with Ambient and Chamber Observations Characterization of Primary Organic Aerosol, Environ. Sci. Technol., 43, 2443-2449, 2009.

Ng, N. L., Kroll, J. H., Chan, A. W. H., Chhabra, P. S., Flagan, R. C., and Seinfeld, J. H.: Secondary organic aerosol formation from $m$-xylene, toluene, and benzene, Atmos. Chem. Phys., 7, 3909-3922, doi:10.5194/acp-7-3909-2007, 2007.

Ng, N. L., Kwan, A. J., Surratt, J. D., Chan, A. W. H., Chhabra, P. S., Sorooshian, A., Pye, H. O. T., Crounse, J. D., Wennberg, P. O., Flagan, R. C., and Seinfeld, J. H.: Secondary organic aerosol (SOA) formation from reaction of isoprene with nitrate radicals $\left(\mathrm{NO}_{3}\right)$, Atmos. Chem. Phys., 8, 4117-4140, doi:10.5194/acp-84117-2008, 2008.

Nordin, E. Z., Eriksson, A. C., Roldin, P., Nilsson, P. T., Carlsson, J. E., Kajos, M. K., Hellén, H., Wittbom, C., Rissler, J., Löndahl, J., Swietlicki, E., Svenningsson, B., Bohgard, M., Kulmala, M., Hallquist, M., and Pagels, J. H.: Secondary organic aerosol formation from idling gasoline passenger vehicle emissions investigated in a smog chamber, Atmos. Chem. Phys., 13, 6101-6116, doi:10.5194/acp-13-6101-2013, 2013.

Parrish, D. D., Stohl, A., Forster, C., Atlas, E. L., Blake, D. R., Goldan, P. D., Kuster, W. C., and de Gouw, J. A.: Effects of mixing on evolution of hydrocarbon ratios in the troposphere, J. Geophys. Res. Atmos., 112, D10S34, doi:10.1029/2006JD007583, 2007.

Platt, S. M., El Haddad, I., Zardini, A. A., Clairotte, M., Astorga, C., Wolf, R., Slowik, J. G., Temime-Roussel, B., Marchand, N., Ježek, I., Drinovec, L., Mocňik, G., Möhler, O., Richter, R., Barmet, P., Bianchi, F., Baltensperger, U., and Prévôt, A. S. H.: Secondary organic aerosol formation from gasoline vehicle emissions in a new mobile environmental reaction chamber, Atmos. Chem. Phys., 13, 9141-9158, doi:10.5194/acp-13-91412013, 2013.

Polo-Rehn, L.: Caractérisation des polluants dus au transport routier?: Apports méthodologiques et cas d'études en Rhône Alpes, PhD thesis, Grenoble Univ., 2013.

Presto, A. A., Miracolo, M. A., Donahue, N. M., and Robinson, A. L.: Secondary Organic Aerosol Formation from High- $\mathrm{NO}_{x}$ Photo-Oxidation of Low Volatility Precursors: n-Alkanes, Environ. Sci. Technol., 44, 2029-2034, doi:10.1021/es903712r, 2010.

Saarikoski, S., Carbone, S., Decesari, S., Giulianelli, L., Angelini, F., Canagaratna, M., Ng, N. L., Trimborn, A., Facchini, M. C., Fuzzi, S., Hillamo, R., and Worsnop, D.: Chemical characterization of springtime submicrometer aerosol in Po Valley, Italy, Atmos. Chem. Phys., 12, 8401-8421, doi:10.5194/acp-12-84012012, 2012.

Shilling, J. E., Zaveri, R. A., Fast, J. D., Kleinman, L., Alexander, M. L., Canagaratna, M. R., Fortner, E., Hubbe, J. M., Jayne, J. T., Sedlacek, A., Setyan, A., Springston, S., Worsnop, D. R., and Zhang, Q.: Enhanced SOA formation from mixed anthropogenic and biogenic emissions during the CARES campaign, Atmos. Chem. Phys., 13, 2091-2113, doi:10.5194/acp-13-20912013, 2013.

Stroud, C. A., Moran, M. D., Makar, P. A., Gong, S., Gong, W., Zhang, J., Slowik, J. G., Abbatt, J. P. D., Lu, G., Brook, J. R., Mihele, C., Li, Q., Sills, D., Strawbridge, K. B., McGuire, M. L., and Evans, G. J.: Evaluation of chemical transport model predictions of primary organic aerosol for air masses classified by particle component-based factor analysis, Atmos. Chem. Phys., 12, 8297-8321, doi:10.5194/acp-12-8297-2012, 2012.

Sun, Y., Zhang, Q., Zheng, M., Ding, X., Edgerton, E. S., and Wang, $X .:$ Characterization and source apportionment of water-soluble organic matter in atmospheric fine particles $\left(\mathrm{PM}_{2.5}\right)$ with highresolution aerosol mass spectrometry and GC-MS, Environ. Sci. Technol., 45, 4854-4861, doi:10.1021/es200162h, 2011.

Sun, Y. L., Zhang, Q., Schwab, J. J., Chen, W.-N., Bae, M.-S., Hung, H.-M., Lin, Y.-C., Ng, N. L., Jayne, J., Massoli, P., Williams, L. R., and Demerjian, K. L.: Characterization of near-highway submicron aerosols in New York City with a high-resolution aerosol mass spectrometer, Atmos. Chem. Phys., 12, 2215-2227, doi:10.5194/acp-12-2215-2012, 2012.

Timonen, H., Carbone, S., Aurela, M., Saarnio, K., Saarikoski, S., Ng, N. L., Canagaratna, M. R., Kulmala, M., Kerminen, V.-M., Worsnop, D. R., and Hillamo, R.: Characteristics, and Watersolubility of Ambient Submicron Organic Aerosol in Springtime in Helsinki, Finland, J. Aerosol Sci., 56, 61-77, 2012.

Ulbrich, I. M., Canagaratna, M. R., Zhang, Q., Worsnop, D. R., and Jimenez, J. L.: Interpretation of organic components from Positive Matrix Factorization of aerosol mass spectrometric data, Atmos. Chem. Phys., 9, 2891-2918, doi:10.5194/acp-9-2891-2009, 2009.

Vestreng, V., Ntziachristos, L., Semb, A., Reis, S., Isaksen, I. S. A., and Tarrasón, L.: Evolution of $\mathrm{NO}_{x}$ emissions in Europe with focus on road transport control measures, Atmos. Chem. Phys., 9, 1503-1520, doi:10.5194/acp-9-1503-2009, 2009.

WHO: Health Effects of Particulate Matter: Policy implications for countries in eastern Europe, Caucasus and central Asia, World Health. Organ., 15, available at: www.euro.who.int (last access: 3 September 2014), 2013.

World Bank: World Development Report 2011: World Development Indicators, Fossil Fuel Energy Consumption, 2011.

Xu, J., Zhang, Q., Chen, M., Ge, X., Ren, J., and Qin, D.: Chemical composition, sources, and processes of urban aerosols during summertime in northwest China: insights from high-resolution aerosol mass spectrometry, Atmos. Chem. Phys., 14, 1259312611, doi:10.5194/acp-14-12593-2014, 2014.

Zhang, Q., Worsnop, D. R., Canagaratna, M. R., and Jimenez, J. L.: Hydrocarbon-like and oxygenated organic aerosols in Pittsburgh: insights into sources and processes of organic aerosols, Atmos. Chem. Phys., 5, 3289-3311, doi:10.5194/acp-5-32892005, 2005.

Zhang, Q., Jimenez, J. L., Canagaratna, M. R., Allan, J. D., Coe, H., Ulbrich, I., Alfarra, M. R., Takami, A., Middlebrook, A. M., Sun, Y. L., Dzepina, K., Dunlea, E., Docherty, K., DeCarlo, P. F., Salcedo, D., Onasch, T., Jayne, J. T., Miyoshi, T., Shimono, A., Hatakeyama, S., Takegawa, N., Kondo, Y., Schneider, J., Drewnick, F., Borrmann, S., Weimer, S., Demerjian, K., Williams, P., Bower, K., Bahreini, R., Cottrell, L., Griffin, R. J., Rautiainen, J., Sun, J. Y., Zhang, Y. M., and Worsnop, D. R.: Ubiquity and dominance of oxygenated species in organic aerosols in anthropogenically-influenced Northern Hemisphere midlatitudes, Geophys. Res. Lett., 34, L13801, doi:10.1029/2007GL029979, 2007 